
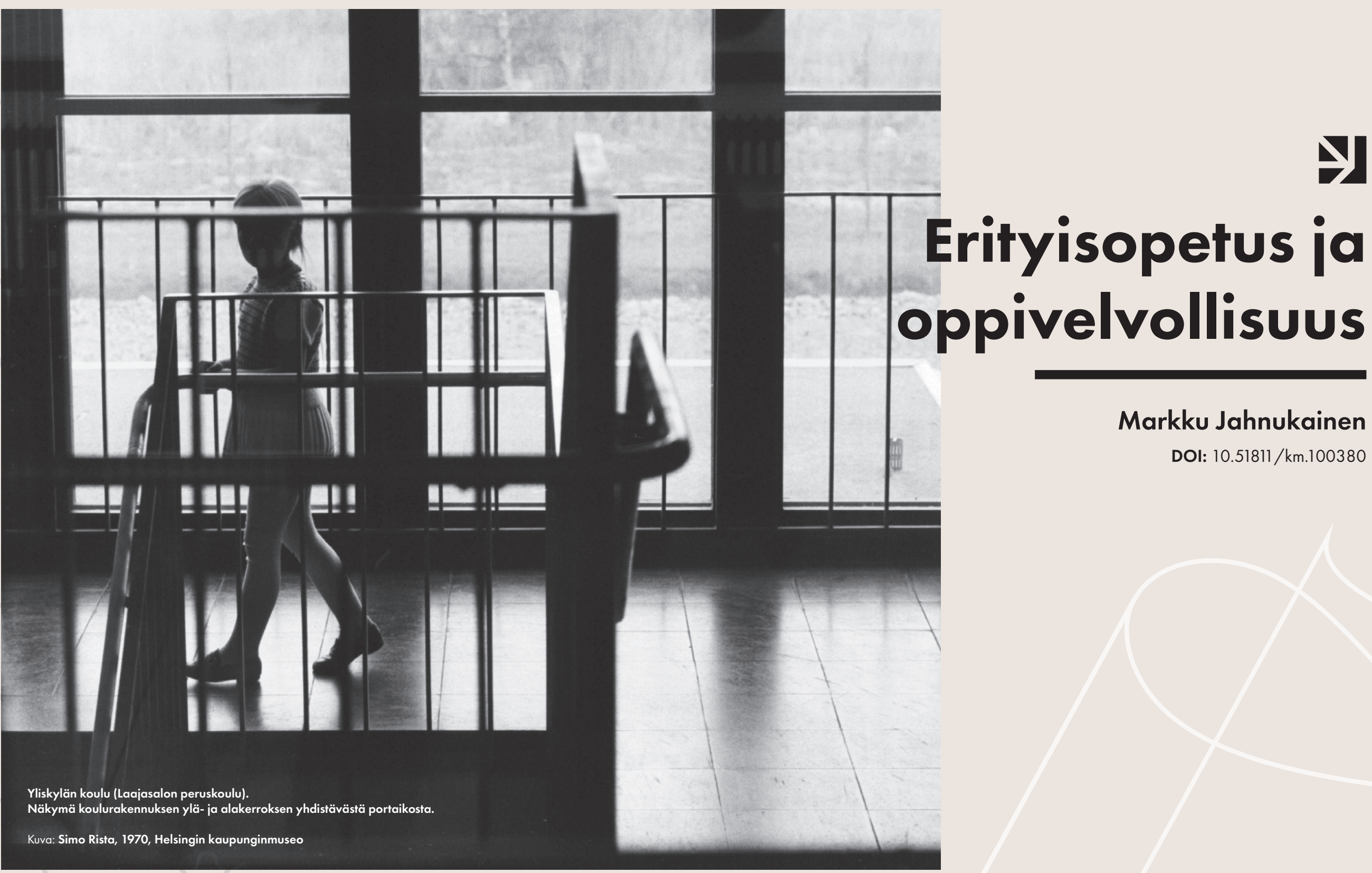

\title{
Erityisopetus ja oppivelvollisuus
}

Markku Jahnukainen

DOI: $10.51811 / \mathrm{km} .100380$ 


\section{Kansakoulun marginaalista yleisopetuksen yhteyteen}

\section{Abstrakti}

Vaikka yleinen oppivelvollisuus säädettiin vuoden 1921 oppivelvollisuuslailla koko ikäluokkaa koskevaksi, moni poikkeavaksi katsottu oppilas jäi vielä pitkään parhaimmillaankin joko erityiskoulu- tai laitossijoitukseen ellei sitten kokonaan opetuksen ulkopuolelle (Tuunainen 2002). Sittemmin tukea tarvitsevien oppilaiden asemaa oppivelvollisuuden suorittamisen suhteen on kohennettu asteittain ja viimeisenä ryhmänä yhtenäiskoulun piiriin siirtyivät vaikeimmin kehitysvammaiset oppilaat syksyllä 1997 (Jahnukainen \& Korhonen 2003). Oppivelvollisuuden ja samalla tuen kestolla on erityisopetuksen kannalta ollut merkittävä funktio: osa vammaisoppilaista opiskelee pidennetyn, eli vuotta aiemmin alkavan ja vuoden pidempään kestävän 11 -vuotisen oppivelvollisuuden mukaisesti. Päätökset oppivelvollisuuden pituudesta tehdään yksilöllisesti. Oppivelvollisuuden pituuden säätely, samoin kuin oppimäärien yksilöllistäminen (Jahnukainen ym. 2020), ovat siis olleet osana eriyttämisen keinovalikoimaa. Yleisellä tasolla kuitenkin suomalainen perusopetusjärjestelmä on toimintamalliltaan varsin yhtenäinen ja reittien jakautuminen alkaakin nykyisellään siirtymässä oppivelvollisuuskoulusta toiselle asteelle (Jahnukainen ym. 2018). Oppivelvollisuusiän korottaminen ja oppivelvollisuuden laajentaminen on ollut pitkän linjan poliittinen hanke, joka nykyisellä Sanna Marinin hallituskaudella on muodostunut keskeiseksi koulutuspoliittiseksi hankkeeksi ja jossa tukea tarvitsevilla oppilailla on ollut keskeinen rooli.

Avainsanat: Erityisopetus Oppivelvollisuus Koulutuspolitiikka
Vammaisuus Kansakoulu Peruskoulu

\section{Johdanto}

Yleisessä kansanopetuksessa, joka maassamme tapahtuu pääasiallisesti vuonna 1921 annetun oppivelvollisuuslain säätämissä puitteissa, tulee esille sellaisten oppivelvollisuusikäisten kasvatus- ja opetuskysymys, jotka joko vajaakykyisyytensä takia eivät voi lainkaan vastaanottaa yhteiskunnan em. lain nojalla heille tarjoamaa perusopetusta tahi joiden opetuksessa tarvitaan erityisiä menetelmiä ja olosuhteita. Ensiksi mainittujen, s.o. varsinaiseen kouluopetukseen kokonaan soveltumattomien lasten hoito, kasvatus ja opetus kuuluu lähinnä lastensuojelu- ja terveydenhuoltoviranomaisille. Viimeksi mainitun lapsiryhmän opetus sen sijaan tapahtuu ainakin oleelliselta osaltaan koulutoimen yhteydessä. (Helsingin kaupunginhallituksen mietintö, Liite 1, 1951.)

Suomi on aikojen saatossa ollut monella tapaa edistyksellinen säätäessään periaatteellisella tasolla yleiseen oppivelvollisuuteen liittyvistä järjestelyistä. Keskeinen kysymys oppivelvollisuuden kohdennuksesta liittyy kuitenkin siihen, miten oppivelvollisten joukko on kulloinkin rajattu iän, yksilöllisten ominaisuuksiensa ja eräiden kontekstitekijöidensä suhteen. Keskeinen yksilöön liittyvä rajaus on ollut arvio oppilaan koulutettavuudesta, joka on linkittynyt erilaisiin ja tarkentuviin käsityksiin vammaisuudesta, poikkeavuudesta ja erityisyydestä (ks. Ahtiainen ym. 2018). Tässä artikkelissa käydään pääpiirteissään läpi viimeisen sadan vuoden aikana tapahtuneet keskeiset muutokset lainsäädännössä ja opetussuunnitelmissa kohdentuen erityisiksi katsottujen oppilaiden oppivelvollisuuden suorittamiseen. Pääpaino on keskeisten lakimuutosten ja niiden vaikutusten tarkastelussa.

Suomalaisessa koulujärjestelmässä vammaisoppilaiden koulutuksen historia alkaa jo Porvoon kuurojen koulun perustamisesta vuonna 1846. Suomen kansakoulun isä Uno Cygnaeus pyrki edistämään myös vammaisten lasten koulutusta, mikä kuitenkin jäi laajemmin toteutumatta - taloudellisista syistä (ks. Tuunainen 2002, 13-14). Kansakoululaitoksen alkuaikoina, ennen yleisen oppivelvollisuuden säätämistä, koulun käyminen olikin ylipäätään lähinnä vapaaehtoisuuteen perustuvaa ja sekä alueellisilla että perheen sosioekonomiseen statuksen liittyvillä taustatekijöillä oli voimakas yhteys sekä koulunkäymiseen että koulumuotoon. Kuten Joel Kivirauma (1987) on tuonut esiin, kansakoulu oli lähtökohtaisesti köyhälistön 
opintoahjo ja varakkaimman kaupunkiväestön keskuudessa yksityiskouluilla oli merkittävä asema. Suurimpiin kaupunkeihin oli kuitenkin jo ennen oppivelvollisuuslakia perustettu myös joitain poikkeaviksi katsotuille lapsille kohdennettuja koulumuotoja, erityisesti Ruotsin mallin mukaisia apukouluja ja muun muassa eristettyjen luokkia ja kasvatuslaitoksia (Kivirauma 2002). Poikkeavien koulutuksen historia onkin rakentunut hyvin pitkään erikoistuneiden instituutioiden, laitosten ja erityiskoulujen varaan (ekskluusio), vastaavasti kuin esimerkiksi lastensuojelun ja psykiatrian aloillakin: avohuollollisiin ja vähemmän leimaaviin ympäristöihin siirtyminen on tapahtunut vasta normalisaation ja yhdenvertaisten palveluiden ideologian vahvistuttua 1960-luvulta alkaen (esim. Harrikari 2019). Erikoistuneet palvelut tulkittiin kansainvälisen mallin mukaisesti oppivelvollisuuskoulun alkutaipaleella edistyksen merkiksi, kuten esimerkiksi Aimo Halila (1950) Suomen kansakoululaitoksen historia -teoksessa ilmaisee.

Kun aluksi oli yhteisiin koululuokkiin jouduttu sisällyttämään mitä erilaisinta oppilasainesta, jota käsiteltiin yhdessä oppimis- ja kehitysedellytysten erilaisuudesta huolimatta, päädyttiin edistyneimmissä maissa jo varhain oppilaiden tarkempaan ryhmittämiseen ja siihen perustuvien erikoiskoulujen tai-luokkien muodostamiseen. (Halila 1950, 99).

\section{Oppivelvollisuuslaki 1921 ja erityisopetuksen "hitaan kehityksen vaihe"}

Vaikka nyt satavuotista historiaa juhliva vuoden 1921 oppivelvollisuuslaki oli selvä parannus koko ikäluokan koulutuksen edistämisessä, se ei kuitenkaan ratkaissut koko ikäluokan - saati sitten poikkeaviksi katsottujen oppilaiden - kouluttamisen mahdollistamista kertaheitolla. Vielä pitkään opetuksen järjestämiseen liittyi useita rajaavia yksityiskohtia, jotka määrittelivät toisaalta opetukseen osallistumisvelvollisuutta ja toisaalta opetuksen järjestämisvelvollisuutta. Oppivelvollisuuslain (101/1921) ensimmäisessä pykälässä säädetään:
Suomen kansalaisten lapset ovat oppivelvolliset tämän lain mukaan, ja astuu voimaan alempana sä̈̈detyssä järjestyksessä. Oppivelvollisuudesta ovat toistaiseksi vapautetut: lähimmästä kansakoulusta viittä kilometriä kauempana asuvat lapset niissä kunnissa, joiden keskimääräinen asukasluku neliökilometriä kohti ei nouse kolmeen; sekä tylsämieliset lapset, joista sä̈̈detään erikseen.

Saman lain neljännessä pykälässä tarkennetaan, että vapautuksen oppivelvollisuudesta oli mahdollista saada ruumiinvian tai heikon terveyden tai heikon käsityskyvyn takia. Kuitenkin jos kunta on järjestänyt erityisopetusta, siihen on velvoittavaa osallistua. Erikseen säädetään $13 \$$ mukaan, että kaupunkikunnan, jossa on vähintään 10000 asukasta, tulee järjestää erityisopetusta.

Oppivelvollisuuslain säätämisen jälkeisinä vuosikymmeninä tehtiin vielä joitain tarkennuksia poikkeaviksi katsottujen lasten koulunkäynnin lainsäädäntöön, kuten vuoden 1934 asetus kuuromykkäin ja sokeain oppilaitoksista (372/1934), joka määritteli vammaisten lasten koulujen ylläpidon valtion tehtäväksi (Merimaa 2011). Heti sotien jälkeen säädetty Invaliidihuoltolaki (907/1946) kohdistui sotainvalidien ammatilliseen kuntouttamiseen, mutta samalla se välillisesti edisti pitkällä aikavälillä myös vammaisten lasten kuntoutusmenetelmien aktiivista kehittämistä (Tuunainen 2002).

Oppivelvollisuuden alkuvaiheessa oli siis monin eri perustein mahdollista jäädä lain suomin edellytyksin kansakoulun ulkopuolelle kokonaan tai osittain, ja tämä koski etenkin lapsia, jotka nykykäsittein olisivat olleet erityisopetuksen kohderyhmää. Ajanjakso onkin aiemmin nimetty "erityisopetuksen hitaan kehityksen vaiheeksi" (Tuunainen \& Ihatsu 1996). Samalla tämä vaihe on ollut palvelurakenteeltaan voittopuolisesti erityiskoulujen ja -laitosten (Kivirauma 1989) ja erillisen erityisopetuksen aikakautta (Moberg 2002). 


\section{Apukouluasetus sekä kansakoululakien muutoslait}

\section{0-luvulla}

Tämän artikkelin alussa siteerattu ote vuodelta 1951 on Helsingin kaupunginhallituksen mietinnön liitteestä, joka on aikanaan toiminut merkittävänä dokumenttina erityisopetuksen asian edistämisessä. Edellä mainittujen säädösten pohjalta etenkin suuremmissa kaupungeissa yleisen oppivelvollisuuden laajeneminen alkoi vaatia uudenlaisia toimenpiteitä sen laajenevan oppilasjoukon osalta, joiden älyllisen vajavaisuuden vuoksi (Lasten erityishuolto ja -opetus Suomessa 1955, 93) ajateltiin vaativan erityisiä menetelmiä ja olosuhteita. Helsingin kaupunki asetti jo vuonna 1945 komitean tutkimaan poikkeuksellisten lasten koulunkäynnin ja jälkihuollon järjestämistä. Kyseinen dokumentti on merkittävä myös siinä suhteessa, että komitean sihteerinä toimi sittemmin suomalaisen erityispedagogiikan (aluksi suojelu- ja parantamiskasvatusoppi) ensimmäiseksi oppituolinhaltijaksi valittu Niilo Mäki. Hän toimi myös lukuisissa komiteoissa asiantuntijana; apukouluasetuksessa (32/1952) näkyvätkin vaikutteet myös samaisen mietinnön liitteenä 2 raportoidusta Mäen tutkimustyöstä entisten apukoululaisten seurantatutkimuksen parissa (Mäki 1951). Muun muassa asetuksen jälkihuoltovelvollisuus on suoraan Helsingin kaupunginhallituksen liitteessä esitettyyn pohjautuva; kiinnostavasti kyse on edelleen ajankohtaisesta aiheesta (ks. myöhemmin oppivelvollisuuden laajentaminen). Apukouluasetuksen merkitystä korostaa se, että kyse oli pitkään suurimmasta erityisopetuksen osa-alueesta (ks. Kivirauma, 2002) ja siten sen merkitys koulutettavien mutta heikkomielisten tai heikkolahjaisten lasten osalta, sekä toisaalta erityiskoulumuotoisen opetuksen osalta, tuli olennaiseksi valtakunnallisesti. Ennen apukouluasetusta eivät kyseisen opetusmuodon oppilaat voineet saada kansakoulun päästökirjaa, ainoastaan oppimäärän osoittavan päästötodistuksen. Päästökirjan saaminen mahdollistui apukouluasetuksen myötä (Lasten erityishuolto ja -opetus Suomessa 1955,96$)$ ja siten kyseisen koulumuodon käyneiden asema parani.

Apukouluopetuksen roolin vahvistaminen erillisenä osana oppivelvollisuuden suorittamista jatkui edelleen vuosien 1957 ja 1958 kansakoululain ja -asetuksen muutoksissa (246/1957 ja 321/1958), joissa erityisopetus sai erityisaseman, sillä apukouluun, tarkkailuluokalle tai muuhun erityisope- tukseen siirrettyä ei saatu ottaa varsinaiseen kansakouluun tai kansalaiskouluun (Merimaa 2011). Samassa yhteydessä jo joillain paikkakunnilla Ruotsin mallin mukaan aloitettu tarkkailuopetus (observationklass) sai virallisen asemansa (Kivirauma 2002). Kyseinen erityisopetuksen muoto on sittemmin yhdessä apukouluopetuksen kanssa muodostunut tunnetuimmaksi erityisopetusta määrittäväksi ja usein negatiivisia konnotaatioita sisältäväksi toimintamalliksi (ks. Moberg 1979). Kuitenkin myös oppivelvollisuudesta vapauttaminen oli edelleen mahdollista:

Lasta älköön pidettäkö kansakoulun oppilaana, jos hänen koulunkäyntinsä ruumiinvian, sairauden tai sielullisen poikkeavuuden vuoksi on katsottava vahingolliseksi tai hyödyttömäksi. Tällainen lapsi on vapautettava oppivelvollisuudesta, mikäli hänelle ei ole järjestetty opetusta tämän lain mukaisessa erikoiskoulussa. (Kansakoululaki 246/1957, S 44).

\section{Peruskoulu ja erityisopetuksen ekspansio}

Siirtymistä rinnakkaiskoulujärjestelmästä yhtenäiseen peruskouluun valmisteltiin pitkään lukuisissa komiteoissa alkaen Yrjö Ruudun johtamassa koulujärjestelmäkomiteassa (KM 1948:1) ja edelleen kymmenisen vuotta myöhemmin R.H. Oittisen johtamassa kouluohjelmakomiteassa (KM 1959:11). Molemmat saivat ristiriitaisen poliittisen vastaanoton ja vasta seuraavalla vuosikymmenellä laki yhtenäiskoulusta (Laki koulujärjestelmän perusteista 467/1967) hyväksyttiin vasemmistoenemmistöisen eduskunnan voimin (Ahonen 2003, 141). Lain hyväksymistä edelsi kahden rinnakkaisen komitean, peruskoulukomitean ja koulunuudistuskomitean valmistelutyö. Erityisesti peruskoulukomitean johtavana ajatuksena oli yhdenvertaisen opetuksen järjestäminen koko ikäluokalle. Peruskoulukomitean I osamietinnössä vuodelta 1965 (KM 1965:A7) todetaankin, että "koulujärjestelmä tulee olla yhtenäinen ja kaikkien lasten opetus on peruskoulussa yleensä yhteistä ja samansisältöistä, mutta aine- ja kurssivalintaan perustuen asteittain eriytyvää”.

Aika ei kuitenkaan ollut vielä kypsä siihen, että edelleen valtaosin erillisissä kouluissa ja luokissa toteutettavaa erityisopetusta olisi käsitelty in- 
tegroidusti osana yhtenäisen peruskouluopetuksen suunnittelua. Siten erityisopetuksen toteuttamiskysymyksiä selvitettiin erikseen nimetyssä erityisopetuksen suunnittelukomiteassa, joka tuotti kaksi mietintöä (KM 1970:A16; KM 1971:A26). Suunnittelukomitean tehtävänä oli kuitenkin kytkeä erityisopetus alusta asti uuteen koulujärjestelmään. Ensimmäinen osamietintö käsitteli sekä erityisopetuksen nykytilan ja tarpeen määrällistä arviointia että mahdollisuuksia toteutuksen suuntaviivoja ja toisessa osamietinnössä keskityttiin opetussuunnitelmallisiin kysymyksiin. Ensimmäisessä osamietinnössä on varsin modernisti tuotu esiin ehdotukset erityisopetuksen oppilaiden ja muiden oppilaiden opettamiseksi samassa opetusryhmässä sekä erityisopettajan ja peruskoulun opettajan yhteisopetuksesta samanaikaisopetuksena:

Lisäksi voitaisiin yhdistää tarkkailuluokan oppilaat joissakin tapauksissa yleisen peruskoulun opetusryhmään siten, että luokassa opettavat samanaikaisesti sekä peruskoulun opettaja, että erityisopettaja. Menettely sopii hyvin esim. käytännön aineiden opetukseen. (KM 1970; A16, 155.)

Taustalla on nähtävissä tuon ajan kotimaisessa (Eriksson 1967) sekä kansainvälisessä kriittisessä tieteellisessä keskustelussa (Nirje 1969) voimallisesti esillä olleet normalisaation lähtökohdat, jotka todennäköisesti ovat olleet ainakin komitean tutkijajäsenten ( $\mathrm{mm}$. erityispedagogiikan professorit Niilo Mäki ja Erkki Saari, lastenpsykiatrian dosentti, myöhemmin professori Terttu Arajärvi) tietoisuudessa. Varsinainen integraatio-ajattelun ja käsitteistön tukevampi rantautuminen suomalaiseen keskusteluun kesti kuitenkin vielä tovin (Moberg \& Ikonen 1980; Moberg 2002).

Vaikka peruskoulu oli suunniteltu yleisrakenteeltaan yhtenäiseksi, sen sisään jäi poliittisena kompromissina (ks. Numminen 2020, 360) toisaalta aiemmasta rinnakkaisjärjestelmästä periytyvä tasokurssirakenne ja toisaalta erityisopetuksen laajeneva järjestelmä rakentui osaltaan sisäiseksi kaksoisjärjestelmäksi (ks. Naukkarinen 2002). Toisin sanoen, heterogeenisen oppilasaineksen kouluttamiseen yhtenäiskoulussa tarvittiin edelleen sisäisiä eriyttämisen keinoja. Peruskoulun asteittain alkaneesta laajentumisesta koko Suomeen alkaakin erityisopetuksen määrällinen laajentuminen, jota on kuvattu lukuisissa tutkimuksissa (esim. Jahnukainen 2006; Kivirauma 1989; Lintuvuori 2019). Aiemmin luki- ja puhevaikeuksiin pienimuotoisemmin käytetty klinikkatyyppinen osa-aikainen erityisopetus, joka sittemmin määriteltiin laaja-alaiseksi erityisopetukseksi, oli keskeinen tapa vastata heterogeenisyyden haasteeseen ja tuoda niin sanottua kokoaikaista, erityisluokka- ja kouluopetusta keveämpää matalan kynnyksen palvelua perusopetukseen. Tämä erityisopetuksen toimintamalli laajeni muutamassa vuodessa kymmeniin tuhansiin oppilaisiin ja seuraavien vuosikymmenien aikana ylittyi 100000 oppilaan rajapyykki (Lintuvuori 2019, ks. kuvio 1). Myös erityisopettajakoulutusta oli tarvetta laajentaa useampaan eri yliopistoon ja kohderyhmäspesifeistä koulutuslinjoista siirryttiin kohden laaja-alaisempaa erityisopettajuutta (Hautamäki ym. 1996).

\section{Kaikille yhteisen oppivelvollisuuskoulun lupauksen täyttyminen 1980- ja 1990-luvuilla}

Kaikille yhteisen koulun idea on toteutunut suomalaisessa oppivelvollisuuskoulussa asteittain. Eräs keskeinen rajapyykki erityisopetuksen osalta on peruskoululain (476/1983) uudistus, jolloin koko ikäluokan integroituminen samaan koulujärjestelmään eteni jälleen pari askelta. Lain tullessa voimaan vuoden 1985 syksystä alkaen oppivelvollisuusikäistä lasta ei enää sen jälkeen ole voinut vapauttaa oppivelvollisuudesta, ei edes vammaisuuteen liittyvillä perusteilla. Samalla integraatio eteni järjestelmätasolla, sillä lievästi ja keskiasteisesti kehitysvammaiset lapset siirtyivät sosiaalitoimesta osaksi perusopetusta, vaikeimmin vammaisten pysyessä edelleen opetustoimen ulkopuolella (Merimaa 2011). 1980-luvun loppupuolella silloinen kouluhallitus valmisteli erityisopetuksen kohderyhmille erilliset valtakunnalliset opetussuunnitelmat ja esimerkiksi apukoulunimike vaihtui mukautetuksi opetukseksi (EMU) ja tarkkailuopetus sopeutumattomien erityisopetukseksi (ESY, kirjain Y viittaa yleiseen opetussuunnitelmaan) (ks. Hautamäki \& Hilasvuori 2015).

Yleisemmin merkittävä oli saman lakiuudistuksen yhteydessä toteutettu luopuminen tasokurssijärjestelmästä (suppea, keskikurssi ja laaja), joka oli määrittänyt myös oppivelvollisten jatko-opintokelpoisuutta. Tätä voidaan pitää viimeisenä varsinaisen rinnakkaiskoulujärjestelmän jäänteen häviä- 
misenä peruskoulusta (Lampinen ym. 2003), vaikkakin voidaan ajatella, että aina näihin päiviin saakka tämä on elänyt perusasteen jälkeisen koulutuksen jakautumisena ammatilliseen koulutukseen ja akateemiseen lukiokoulutukseen (esim. Ahonen 2003). Tätä jakoa pyrittiinkin poistamaan nuorisokouluhankkeella 1980-luvun lopulla (Meriläinen \& Varjo 2006), mutta se ei koskaan toteutunut suunnitellulla tavalla (Lampinen ym. 2003)

Tasokurssien poistaminen ei kuitenkaan vielä ollut viimeinen sinetti koko ikäluokan yhtenäisen koulutuksen suhteen. Vaikka itse oppivelvollisuudesta ei enää vuoden 1985 jälkeen voinut vapauttaa myöskään vaikeimmin kehitysvammaisia, tämä joukko (vuonna 1997 noin 900 oppilasta, Jahnukainen \& Korhonen 2003) liitettiin viimeisenä ryhmänä sosiaalitoimen alaisuudesta opetustoimeen perusopetuslain muutoksella (1368/1996) vasta alkaen syksystä 1997. Vähintään symbolisessa mielessä tämä on merkittävä rajapyykki, jonka myötä jo 1800-luvun lopulta alkanut yleisen oppivelvollisuuden hanke "valmistui" ulottuen Uno Cygnaeuksen hengessä kattamaan kaikki oppivelvollisuusikäiset. Käytännössä kuitenkin vaikeimmin vammaisten opetus järjestettiin usein edelleen erillisissä yksiköissä irrallaan muusta perusopetuksesta (Jahnukainen \& Korhonen 2003). Vaikka tilanne on asteittain tästä parantunut, vuonna 2013 kerätyn valtakunnallisen aineiston perusteella vielä yli neljännes vaikeimmin kehitysvammaisten ryhmistä oli sijoitettu täysin erilleen muusta perusopetuksesta (Pirttimaa ym. 2015).

\section{Kohden 2000-luvun oppimisen ja koulunkäynnin tuen} järjestelmäö

Kun koko ikäluokka vihdoin saatiin perusopetuksen pariin lukuvuoden 1997 alusta, jatkui erityisopetusjärjestelmän sisäinen hienosäätö, mikä on jatkunut aina näihin päiviin saakka (ks. Ahtiainen 2017; Lintuvuori 2019; Pulkkinen 2019). Perusopetuslain (628/1998) erityisopetusta koskevat märitelmät tekivät mahdolliseksi kokoaikaisen erityisopetuksen ${ }^{1}$ antamisen myös kokonaan yleisopetuksen yhteydessä. Tämän jälkeen sekä erityisopetuksen kokonaisoppilasmäärä että yleisopetuksen koulujen yhteyteen - joko erityisluokkaan tai osin tai kokonaan yleisopetuksen ryhmään - integroitujen oppilaiden määrä alkoi kasvaa (Jahnukainen 2006; Lintuvuori ym. 2017; ks. kuvio 1). Taustalla oli laajempi paradigmamuutos erityisopetuksen järjestämiseksi erillisen erityisopetuksen sijaan yhä useammin yleisopetuksen yhteydessä.

Kuviossa 1 havainnollistuvaan 2000-luvun alun voimalliseen erityisopetuksen oppilasmäärän kasvuun linkittyy kuitenkin monta lähes samanaikaisesti tapahtunutta muutosta (ks. Jahnukainen 2006). Ensinnäkin perusopetusjärjestelmään liitettiin täysin uusina ryhminä edellä mainitut vaikeimmin kehitysvammaiset oppilaat sekä esiopetuksen oppilaat, joiden osalta myös erityisopetukseen ottaminen tai siirtäminen oli mahdollista. Myös erityiskoulujen hallinnollinen yhdistäminen muiden koulujen alaisuuteen lisääntyi. Samaan aikaan sekä kansainvälisesti että kotimaassa tapahtui uusien psyko-medikaalisten diagnoosien (mm. ADHD, autismi, dysfasia) nopea yleistyminen (ks. Kirjavainen ym. 2014a, Wishart \& Jahnukainen 2010). Muun muassa näihin ryhmiin kuuluvien oppilaiden sijoittaminen osin tai kokoaikaisesti perusopetukseen ryhmiin erityisopetukseen otettuna tai siirrettynä oppilaana mahdollistui perusopetuslaissa (628/1998) esitetyn henkilökohtaisen opetuksen järjestämistä koskevan suunnitelman (HOJKS) avulla. Kun tuolloin kunnat saivat vielä rahoituksellisesti 50 prosentin korotuksen valtionosuuksiin kyseisistä erityisopetuksen oppilaista, osa kasvusta saattoi kannustaa erityisoppilasstatuksen määrittelyyn aiempaa keveämmin perustein. Vuonna 2010 tuli voimaan valtionosuusuudistus (Laki kunnan peruspalvelujen valtionosuudesta 1704/2009), jossa tämä kannustin poistui. Reformien vaikutuksia tarkastellut tutkimus osoittaakin, että erityisesti rahoituslain muutos vaikutti oppilasmärän kasvun taittumiseen, varsinkin heti 2010-luvun alkuvuosina (Pulkkinen ym. 2020).

\footnotetext{
Virallinen hallintotermi niin sanotulle kokoaikaiselle erityisopetukselle oli vuoteen 2011 saakka erityisopetukseen ottaminen tai siirtäminen ja sen jälkeen erityinen tuki (ks. esim. Jahnukainen ym. 2012).
} 


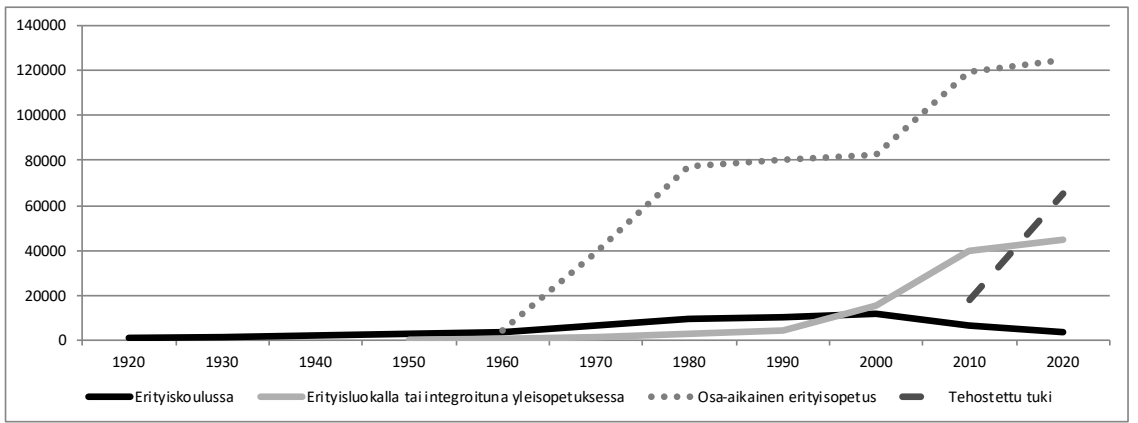

Kuvio 1. Erityisopetuksen päämuotojen oppilasmäärän historiallinen kehitys kymmenvuosittain 1920-2020 (Lähteet: Kivirauma 1989; Jahnukainen 2011; SVT 2020)

Vammaisten henkilöiden oikeutta päästä opetukseen tavallisissa kouluissa ajaneen Salamancan julistuksen (UNESCO 1994) jälkeen aiempi integraationa tunnettu käsite alkoi suomalaisessakin keskustelussa muuntua kansainvälisten mallien mukaisesti inkluusioksi (Moberg 2002). Selkeimmin tämän voi nähdä sisäisenä kehittämisenä kaikille yhteisen oppivelvollisuuskoulun suuntaan myös toiminnallisesti Erityisopetuksen strategia -dokumentissa (OPM 2007). Monien käytännön seikkojen osalta inkluusion suomalainen määrittely on kuitenkin edelleen ${ }^{2}$ jäänyt monitulkintaiseksi: kunnilla perusopetuksen järjestäjinä on edelleen lain (Laki perusopetuslain muuttamisesta 642/2010, \$17) suomat valtuudet järjestää erityisopetus "oppilaan etu ja opetuksen järjestämisedellytykset huomioon ottaen muun opetuksen yhteydessä tai osittain tai kokonaan erityisluokalla tai muussa soveltuvassa paikassa”. Tämä muotoilu tukeutuu edelleen pikemminkin integraatioideologiaan ja niin sanotun vähiten rajoittavan ympäristön periaatteeseen kuin jo lähtökohdissaan kaikille yhteisen, inklusiivisen koulun toimintamalliin (ks. Moberg 2002; Paju 2021).

Sanna Marinin hallituksen hallitusohjelman (VN 2019) mukaisesti on kuitenkin paraikaa käynnissä Oikeus oppia -kehittämisohjelma (2020-2022), jonka keskeisenä tavoitteena on määritellä inklusiivisen opetuksen käytännöt ja selkeyttää alueen lainsäädäntö.
Vuoden 2010 perusopetuslain muutoksessa (624/2010) ja edelleen opetussuunnitelmauudistuksessa (OPH 2011) lanseerattiin oppimisen ja koulunkäynnin tuen järjestelmä, jossa kevyimmän tuen portaan, eli yleisen tuen, avulla pyritään kouluyhteisön ja yleisopetuksen roolia korostaen kohtaamaan oppilaiden yksilölliset tarpeet. Yleinen tuki on kaikille tarjottava tukimuoto ja se edeltää varsinaisia erityisopetuksellisia tuen muotoja, tehostettua ja erityistä tukea (Jahnukainen ym. 2012). Uusi tukimuoto, tehostettu tuki, on muodostanut oman oppilasjoukkonsa vaativamman erityisen tuen ja toisaalta osa-aikaisen erityisopetuksen välimaastoon. Tehostetun tuen käytössä on kuitenkin havaittu suuria eroja eri kuntien välillä ja sen roolia ollaan tarkentamassa (esim. Lintuvuori 2019). Huomionarvoista on, että osa-aikainen erityisopetus on nykyään eräs niistä tukimuodoista, joita voidaan tarjota muun opetuksen ohessa kaikilla eri tuen tasoilla. Siten esimerkiksi kuvion 1 oppilasmääriä ei voi suoraan laskea yhteen, sillä niissä on osin päällekkäisyyttä. Jo vuoden 1998 perusopetuslain voimaan tulon jälkeen erillisten erityiskoulujen määrä sekä niissä opiskelevien oppilaiden oppilasmäärä on johdonmukaisesti vähentynyt ja vastaavasti yleisopetuksessa joko kokonaan tai osittain opiskelevien erityisen tuen oppilaiden määrä kasvanut (esim. Jahnukainen \& Itkonen 2021).

\section{Pidennetty oppivelvollisuus ja oppimäärän mukauttaminen erityisopetuksen keinoina}

Kuten edellä esitetystä käy ilmi, sen lisäksi että oppivelvollisuudesta on aina syksyyn 1985 voinut saada kokonaan vapautuksen vammaisuuteen liittyvistä syistä, erityisoppilaiden oppivelvollisuutta on lisäksi säännelty oppimäärän mukauttamisen ja oppivelvollisuuden pidentämisen keinoin. Eri oppilasryhmien erillisistä opetussuunnitelmista (mm. kuulovammaisten EKU, näkövammaisten ENÄ, harjaantumisopetuksen EHA1 ja EHA2) luovuttiin 2000-luvun alkupuolella, jolloin määriteltiin uudelleen perusopetuksen perusteet. Oppivelvollisuuden suorittamisen kannalta merkittävin muutos oli, että apukoulun seuraajana olleen mukautetun erityisopetuksen (EMU) opetussuunnitelman ryhmämuotoisuus poistui ja erääksi erityisopetukselliseksi keinoksi myös yleisopetuksen yhteydessä mahdollistui yleisen oppimäärän 'mukauttaminen', joka myöhemmin korvattiin ensin erilaajuisen oppimäärän käsitteellä (Virtanen 2002) ja 
sittemmin yksilöllistämisellä. Termimuutoksilla haluttiin korostaa opetuksen järjestämisen henkilökohtaistamista. Edelleen voimassa olevalla menettelyllä oppilaan oppimäärää voidaankin yksilöllistää joko yhden, useamman tai kaiken opetuksen suhteen osana henkilökohtaista oppimisen järjestämistä koskevaa suunnitelmaa (HOJKS) ja tämä menettely onkin yleistynyt vuosien mittaan (Kirjavainen ym. 2014b). Lisäksi vaikeimmin kehitysvammaiset oppilaat voivat opiskella toiminta-alueittain oppiainejaon sijaan (OPH 2016).

Yksilöllistäminen liittyy oppivelvollisuuden keston säätelyyn, sillä kokonaan yksilöllistetyn opetussuunnitelman mukaisesti opiskeleminen linkittyy pidennettyyn oppivelvollisuuteen, eli niin sanottuun 11-vuotiseen oppivelvollisuuteen, josta säädettiin vuoden 1983 perusopetuslaissa. Pidennetty oppivelvollisuuden piiriin kuuluvatkin vaikeimmin vammaiset tai vaikeasti sairaat lapset (HE 86/1997 vp):

Jos vammaista lasta ei hänen vammansa vuoksi voida opettaa yhdeksänvuotisessa peruskoulussa, hänen oppivelvollisuutensa alkaa vuotta 2 momentissa mainittua ajankohtaa aikaisemmin ja kestää yksitoista vuotta. (Perusopetuslaki 476/1983, \$32).

Nykyinen lainsäädäntö mahdollistaa pidennetyn oppivelvollisuuden alkamisen jo 5-vuotiaana eli vuotta ennen esiopetuksen aloittamista (HE86/1997 vp). Siten riippuen aloitusiästä pidennetyn oppivelvollisen oppivelvollisuus täyttyy joko 16- tai $17-$ vuotiaana (OPH 2020). Vuosien 1998-2014 koulutustilastoihin perustuva tarkastelumme (Jahnukainen ym. 2020) osoitti, että oppimär̈ien yksilöllistämiseen liittyy se, että matalamman sosioekonomisen taustan omaavat ja vuoden lopulla syntyneet sekä pojat ovat yliedustettuina yksilöllistämistoimissa (Jahnukainen ym. 2020). Lisäksi Lintuvuori ym. (2017) tutkimuksessa havaittiin suuria alueellisia ja kuntakohtaisia eroja yksilöllistämisen käytössä. Tässä mielessä yksilöllistämiseen saattaa liittyä uudenlaisia epätasa-arvoistavia mekanismeja, jotka ovat uhka tukea tarvitsevien oppilaiden oppivelvollisuuden toteutumiselle.

\section{Oppivelvollisuusiän muutokset ja oppivelvollisuuden \\ laajentaminen}

Yleisen oppivelvollisuuden kestoa on muutettu ja hienosäädetty oppivelvollisuuskoulun historian aikana pariin otteeseen. Alkuperäisessä vuoden 1921 oppivelvollisuuslaissa määritellään oppivelvollisuuden alkavan sinä syksynä, kun lapsi täyttää 7 vuotta ja päättyvän sinä keväänä kun 13 vuotta tulee täyteen. Kansakoulu oli siis 6-vuotinen, joskin lisäksi edellytettiin osallistumaan "pääasiallisesti käytännön elämään” valmistavaan jatko-opetukseen $(\$ 3$ ja $\$ 8)$.

Vuoden 1957 kansakoululaissa (247/1957) määritellään kansakoulun kesto 6-vuotiseksi ja kansalaiskoulun 2-vuotiseksi tai, "mikäli olosuhteet niin vaativat, 1-vuotiseksi," jolloin varsinainen kansakoulu on 7-vuotinen. Kouluhallituksen luvalla maalaiskunnat saivat lyhyemmän vaihtoehdon korvata myös kurssilla, jonka piti kuitenkin sisältää vähintään 200 oppituntia (\$4). Oppivelvollisuuden täyttymisen yläikäraja oli kuitenkin tässä vaiheessa korotettu 16 ikävuoteen, tarkalleen ottaen siihen kevääseen, jolloin lapsi täyttää 16 vuotta.

Peruskouluun siirtymisestä säädettäessä (Laki koulujärjestelmän perusteista 467/1967) aiemmat kansakoulu, kansalaiskoulu ja keskikoulu yhdistettiin "yleistä peruskasvatusta antavaksi." Oppivelvollisuusikä pysyi tässä vaiheessa samana kuin edeltävässä kansakoululaissa. Muutos oppivelvollisuusikään tuli vasta vuonna 1985 voimaan astuneessa peruskoululaissa (647/1983), jolloin oppivelvollisuuden suorittaminen määriteltiin toisaalta peruskoulun oppimäärän suorittamisena $(\$ 34)$ tai 7-vuotiaana aloitetun oppivelvollisuuden 10-vuotisuuden kautta (\$32). Siten oppivelvollisuus päättyi viimeistään oppilaan täyttäessä 17 vuotta:

Oppivelvollisuuden suorittaminen alkaa syyslukukauden alussa sinä vuonna, jona lapsi täyttää seitsemän vuotta, ja kestää, jollei oppivelvollisuutta sitä ennen ole täytetty, kymmenen vuotta. (Peruskoululaki 647/1983). 
Oppivelvollisuuden pidentäminen oli kuitenkin jo heti peruskoulun säätämisen jälkimainingeista mukana erilaisissa poliittisissa keskusteluissa: 12-vuotiseen oppivelvollisuuteen siirtyminen on ollut mukana erityisesti vasemmistokeskustalaisessa ajattelussa (Meriläinen 2011), vahvistuen uudelleen 1990-luvun lopulla (Arhinmäki 2020). Rinnakkaisena hankkeena opetusministeriön visiotyön pohjalta syntyi koulutustason nostamiseen ja kilpailukyvyn parantamiseen linkittyvä nuorisokouluajattelu 1980-luvun loppupuolella (Lampinen ym. 2003). Tarkoitus oli integroida akateeminen ja ammatillinen yleissivistävä koulutus yhteiseksi nuorisoasteeksi (Volanen 2000). Hanke ei kuitenkaan edennyt kokeilulakia pidemmälle, joskin perinnöksi jäi edelleen toiminnassa oleva kaksoistutkintomahdollisuus (Meriläinen 2011).

Uudelleen aktiiviselle poliittiselle agendalle oppivelvollisuuden pituuden säätely nousi ensin vuonna 2009 vasemmistoliiton kansanedustaja Paavo Arhinmäen toimenpidealoitteessa (TPA 88/2009vp), joka kuitenkin raukesi myöhemmin valiokuntakäsittelyn jälkeen. Pidemmälle asia eteni Jyrki Kataisen (kok.) hallituskaudella (2011-2014) nuorisotakuun yhteydessä. Tällöin sosiaalidemokraatit ja opetusministeri Krista Kiuru esittivät oppivelvollisuusiän nostoa yhdellä vuodella. Tämä olisi siis tarkoittanut 7-vuotiaana peruskoulunsa aloittaneille ja yhdeksässä vuodessa suorittaneille velvollisuutta jatkaa vähintään yhden vuoden joko toisen asteen opinnoissa tai perusopetuksen lisäopetuksessa tai valmentavassa koulutuksessa (Luonnos hallituksen esitykseksi 7.5.2014). Eduskunnan päätös ei kuitenkaan toteutunut, koska Kataisen hallitusta seurannut Alexander Stubbin (kok.) hallitus päätti luopua ikärajan nostosta kehysriihessä (Arhinmäki 2020). Vasemmistoliitto nosti asian uudelleen keskusteluun syksyllä 2014 lakialoitteen (LA59/2014 vp) muodossa, mutta se ei enää edennyt pidemmälle eduskuntakauden kääntyessä loppua kohden.

Kevään 2018 hallitusneuvotteluissa yhteinen tahtotila löytyi ja Antti Rinteen (sd.) hallituksen hallitusohjelman Osaava ja osallistava Suomi keskeisimmiksi koulutuspoliittisiksi tavoitteiksi asetettiin toimet koulutus- ja osaamistason nostamiseksi kaikilla koulutusasteilla, oppimiserojen kaventumisen ja tasa-arvon lisääntymisen. Sittemmin Sanna Marinin (sd.) hallitus jatkoi samalla hallitusohjelmalla (VN 2019) ja opetusministeri Li
Andersson (vas.) edisti kokonaisuutta, jota kutsutaan oppivelvollisuuden laajentamiseksi. Laaja kokonaisuus pitää sisällään sekä oppivelvollisuusiän korottamisen 18 ikävuoteen, toisen asteen opintojen maksuttomuuden sekä tukitoimen lisäämisen perusopetukseen ja nivelvaiheen valmentavien opintojen kehittämisen (HE 173/2020 vp). Lakia pohjustava hallituksen esitys (HE 173/2020 vp) oli tällä kertaa huomattavasti edellistä perusteellisempi (489 sivua vs. aiempi 84 sivua) ja lain hyväksymistä edelsi laaja kuulemiskierros $^{3}$ sekä vilkas keskustelu niin virallisilla foorumeilla kuin sosiaalisessa mediassakin ${ }^{4}$. Laki hyväksyttiin eduskunnassa syksyllä 2020 astuakseen voimaan 1.8.2021 siten, että 1.1.2021 mennessä oppivelvollisuuttaan suorittamattomat kuuluvat uudistuksen piiriin:

Suomessa vakinaisesti asuvat lapset ovat oppivelvollisia. Oppivelvollisuus alkaa perusopetuslaissa (628/1998) tarkoitetun lukuvuoden alkaessa sinä vuonna, jona lapsi täyttää seitsemän vuotta. Jos perusopetuslaissa tarkoitetulle perusopetukselle säädettyjä tavoitteita ei lapsen vammaisuuden tai sairauden vuoksi ilmeisesti ole mahdollista saavuttaa yhdeksässä vuodessa, alkaa oppivelvollisuus vuotta 2 momentissa säädettyä aikaisemmin (pidennetty oppivelvollisuus). Oppivelvollisuus päättyy, kun oppivelvollinen täyttää 18 vuotta tai kun oppivelvollinen on tätä ennen hyväksytysti suorittanut ylioppilastutkinnosta annetussa laissa (502/2019) tai ammatillisesta koulutuksesta annetussa laissa (531/2017) tarkoitetun tutkinnon taikka niitä vastaavan Ahvenanmaalla suoritetun tai ulkomaisen koulutuksen. (Oppivelvollisuuslaki, 2 S, HE 173/2020 vp).

\section{Erityisopetus ja oppivelvollisuuden laajentamisen muutokset}

Kuten edellä todettiin, oppivelvollisuuden keston säätelyä on jo aiemmin käytetty eräänä erityisopetuksellisena keinona, joskin se on rajautunut varsin pieneen oppilasjoukkoon ja pidentäminen on pääsääntöisesti toteutunut oppivelvollisuuden varhaisempana aloittamisena. Pitkän linjan

\footnotetext{
<https://minedu.fi/oppivelvollisuuden-laajentaminen>

${ }^{4}$ Ks. esim. lyhytviestipalvelu Twitterin aihetunnisteet \#oppivelvollisuus \#oppivelvollisuudenpidentäminen \#oppivelvollisuudenlaajentaminen
} 
erityispedagogisena teemana tuen jatkumisen tarve myös oppivelvollisuuden jälkeisessä koulutuksessa on ollut moneen otteeseen esillä (Mäki 1951; Koro \& Moberg 1981; Kivirauma 1995; Jahnukainen 1997), mutta tuen toteutuminen on ollut puutteellista. Aiempien tutkimusten perusteella tukea tarvitsevien nuorten osalta peruskoulun jälkeisiin opintoihin kiinnittymiseen liittyy entisten erityisoppilaiden osalta selkeitä eroavaisuuksia suhteessa muihin peruskoulun päättäviin (esim. Jahnukainen 1996; Jahnukainen ym. 2018). Opintoihin hakeutuminen, aloittaminen ja tutkinnon suorittamisen ovat edelleen entisten erityisopetuksen oppilaiden osalta selvästi muuta ikäluokkaa matalammalla tasolla (Jahnukainen ym. 2018; Kirjavainen ym. 2016).

Tukea tarvitsevien oppilaiden näkökulmasta jo edellisellä, Juha Sipilän (kesk.), hallituskaudella tehty päätös lukion erityisopetuksesta uuden lukiolain (714/2018) yhteydessä oli merkittävä uudistus. Syksyllä 2021 voimaan astuva säädös mahdollistaa paremmin tukea tarvitsevien nuorten siirtymisen perusopetuksen jälkeen myös lukiokouluun, perinteisemmin erityisopetusta tarjonneen ammatillisen koulutuksen ohella. Oppivelvollisuusiän korotus ei vaikuta vammaisuuden vuoksi pidennettyä, 11-vuotista oppivelvollisuutta suorittavien tilanteeseen muutoin, mutta se mahdollistaa toisen asteen maksuttoman suorittamisen aina 20 ikävuoteen asti, kuten muidenkin nuorten osalta. Erityisoppilaiden osalta oppivelvollisuuden laajentamisen yhteydessä toteutettavia keskeisiä uusia tukitoimia ovat perusopetuksen tehostettu henkilökohtainen oppilaanohjaus (Laki perusopetuslain muuttamisesta 1216/2020, \$11a) sekä nivelvaiheen koulutusten yhtenäistäminen tutkintokoulutukseen valmentavaksi koulutukseksi alkaen syksystä 2022 (Laki tutkintokoulutukseen valmentavasta koulutuksesta 1215/2020). Ohjauksellinen tuki ja erityisopetuksen oppilaiden koulutuspoluista huolehtiminen ovatkin toimia, joita on vahvasti suositeltu jo aina Niilo Mäen (1951) ajoista saakka (Jahnukainen 2005):

Koska tämän lisäksi juuri apukoulun oppilaat muodostavat poikkeuksellisista lapsista laajimman, yhtenäisen ryhmän, on sopivaa pitää heidän jälkihuoltokysymystään koko suunnittelun ensimmäisenä ja tärkeimpänä tehtävänä ja pyrkiä muussa jäIkihuollossa soveltamaan mahdollisuuksien mukaan samoja muotoja. (Helsingin kaupunginhallituksen mietintö, Liite 1, 1951).
Oppivelvollisuuden laajentamisen keskeinen kritiikki on kiinnittynyt siihen, onko koko ikäluokkaa koskeva uudistus tarpeen vai olisivatko kohdennetut toimet tukea tarvitseville olleet riittävät (esim. Johnson \& Kiilakoski 2020). Vaihtoehtoina esitettiin pikemminkin panostamista perusopetuksen kehittämiseen ja perusopetuksen osaamistakuuseen kuin oppivelvollisuuden pidentämiseen (Elinkeinoelämän keskusliitto 2018). Uusi oppivelvollisuuslaki tuo monia uusia velvoitteita kunnille ja koulutuksen järjestäjille seurata oppivelvollisuusikäisten nuorten etenemistä erityisesti putoamisvaarassa olevien oppilaiden suhteen ja näiden käytäntöjen vakiinnuttamiseen menee vielä tovi.

\section{Lopuksi}

Koko ikäluokan oppivelvollisuuskoulun historiassa nykyterminologialla ilmaistuna "tukea tarvitsevien" oppilaiden asema on vahvistunut askel askeleelta. Erityisopetuksen järjestelmä on sadan vuoden aikana sekä määrällisesti että laadullisesti voimakkaasti laajentunut ja pääpaino myös vaativamman tuen osalta on siirtynyt selvästi yleisopetuksen yhteydessä tarjottavaan tukeen erillisen erityisopetuksen sijaan. Tämä on vaatinut monia poliittisia ja käytännöllisiä kehittämistoimia. Uno Cygnaeuksen jo 1800-luvun puolivälissä esittämät ajatukset myös vammaisoppilaiden kouluttamiseksi ovatkin hyvin pitkälle toteutuneet lukuisien välivaiheiden kautta. Vaikka peruskouluun siirtyminen 1970-luvulla oli koulujärjestelmän tasolla merkittävä muutos, koko ikäluokan oppivelvollisuuden suorittamisen näkökulmasta olennaista oli, että vuoden 1983 perusopetuslaki ei enää mahdollistanut kenenkään oppivelvollisuudesta kokonaan vapauttamista. Sekä erityisopetuksen että koko oppivelvollisuusideologian näkökulmasta keskeinen rajapyykki oli syksy 1997, jolloin vähintään symbolisessa mielessä oppivelvollisuuskoulun alkuperäinen idea tuli täydeksi vaikeimmin kehitysvammaisten siirtyessä opetustoimeen. Tässä mielessä vuoden 2020 oppivelvollisuuslaki päivittää myös tuen tarpeessa olevien oppilaiden yhtäläisen oikeuden oppivelvollisuuteen ja tukitoimiin sen suorittamiseksi sekä laajentamiseksi kattamaan myös toisen asteen koulutuksen. Koulutuspoliittinen keskustelu tullee jatkumaan erityisesti toisen asteen koulutuksen maksuttomuuden osalta ja toisaalta odotettavissa on järjestelmän hienosäätöä siinä vaiheessa kun seurantatietoa oppivelvollisuuden laajentamisen eri osa-alueiden toimivuudesta ja vaikuttavuudesta on saatavilla. 


\section{Lähteet:}

\section{Kirjallisuus:}

Ahonen, Sirkka. 2003. Yhteinen koulu. Tasa-arvoa vai tasapäisyyttä. Tampere: Vastapaino.

Ahtiainen, Raisa. 2017. Shades of Change in Fullan's and Hargreaves's models. Theoretical Change Perspectives Regarding Finnish Special Education Reform. Helsingin yliopisto. Kasvatustieteellinen tiedekunta. Helsinki Studies in Education 13.

Ahtiainen, Raisa, Lintuvuori, Meri, Hienonen, Ninja, Jahnukainen, Markku \& Hautamäki, Jarkko 2017. Erityisten nimeäminen ja käsitteet perusopetuksessa lyhyt historia ja nykytila. Teoksessa Toom, Auli, Rautiainen, Matti \& Tähtinen, Juhani (toim.), Toiveet ja todellisuus: Kasvatus osallisuutta ja oppimista rakentamassa. Jyväskylä: Suomen kasvatustieteellinen seura ry, 119-142.

Arhinmäki, Paavo 2020. Oppivelvollisuus pitenee - ei siihen mennyt kuin 20 vuotta. [www-lähde]. > https://www.paavoarhinmaki.fi/blogi/2020/oppivelvollisuuspitenee-ei-siihen-mennyt-kuin-20-vuotta/< (Luettu 9.11.2020)

Elinkeinoelämän keskusliitto 2018. Koulutustakuusta osaamistakuuseen. [www-lähde]. >https://ek.fi/wp-content/uploads/EK_Koulutustakuusta_ osaamistakuu_final_3.12.2018_net.pdf< (Luettu 5.12.2018)

Eriksson, Lars. D. (toim). 1967. Pakkoauttajat. Helsinki: Tammi.

Halila, Aimo 1950. Suomen kansakoululaitoksen historia. IV osa. Oppivelvollisuuskoulun alkuvaiheet 1921-1939. Suomalainen tiedeakatemia. Helsinki: WSOY.

Harrikari, Timo 2019. Lastensuojelun historia. Tutkielma oikeussääntelystä, kulttuurisista kerrostumista ja hallinnan murroksista. Tampere: Vastapaino.

Hautamäki, Jarkko \& Hilasvuori, Touko (2015). Perusopetuslain erityisopetusta koskevat vuoden 2010 muutokset viimeisimpänä vaiheen peruskoulun kehitystä. Teoksessa Jahnukainen, Markku, Kontu, Elina, Thuneberg, Helena \& Vainikainen, Mari-Pauliina (toim.), Erityisopetuksesta oppimisen ja koulunkäynnin tukeen. Kasvatusalan tutkimuksia 67. Turku: Suomen kasvatustieteellinen seura ry, 15-24.

Hautamäki, Jarkko, Kuusela, Jorma \& Mänty, Tarja 1996. Erityisopettajien valmistuminen Suomessa 1960-1994. Teoksessa Blom, Heikki, Laukkanen, Reijo, Lindstrom, Aulis, Saresma Ulla \& Virtanen, Pirkko (1996): Erityisopetuksen tila. Helsinki: Opetushallitus, $75-80$
Helsingin kaupunginhallituksen mietintö, 1951. Poikkeuksellisten lasten koulunkäynnin ja jälkihuollon järjestely (1951). Mietintö 27:1. Helsinki.

Jahnukainen, Markku 1996. Mukautetun ja sopeutumattomien erityisopetuksen oppilasvirrat. Teoksessa Blom, Heikki, Laukkanen, Reijo, Lindstrom, Aulis, Saresma Ulla \& Virtanen, Pirkko (toim.) Erityisopetuksen tila. Helsinki: Opetushallitus, 239-249.

Jahnukainen, Markku 1997. Koulun varjosta aikuisuuteen. Entisten tarkkailuoppilaiden peruskoulun jälkeiset elämänvaiheet. Helsingin yliopisto. Opettajankoulutuslaitos. Tutkimuksia 182.

Jahnukainen, Markku 2005. Koulutus syrjäytymisen ehkäisyssä. Teoksessa Koivula, P. (toim.) Selviytymisen polkuja. Opetusjärjestelyt oppilaan tukena. Vammala: Vammalan kirjapaino, 40-50.

Jahnukainen, Markku 2006. Erityisopetuksen tarve ja muutos. Teoksessa Karvonen, Sakari (toim.), Onko sukupuolella väliä? Hyvinvointi, terveys, pojat ja tytöt. Nuorten elinolot vuosikirja. Helsinki: Nuorisotutkimusverkosto, Nuorisoasiain neuvottelukunta \& Stakes, 119-131.

Jahnukainen, Markku \& Itkonen, Tiina 2021. Steps to inclusion? The role of tiered intervention in Finland and in the United States. Teoksessa Köpfer, Andreas, Powell, Justin \& Zahnd, Raphael (toim.), The International Handbook of Inclusive Education: Global, National and Local Perspectives on Inclusive Education. Barbara Budrich Verlag, 345-356.

Jahnukainen, Markku, Kivinen, Aapo \& Kortelainen, Mika 2020. Yksilöllistä opetusta ennustavat tekijät ja suhteellisen iän vaikutus erityisopetuksessa. Kansantaloudellinen aikakauskirja 116 (1), 73-89.

[www-lähde]. <https://www.taloustieteellinenyhdistys.fi/wp-content/ uploads/2020/02/KAK_1_2020_WEB-75-91.pdf> (Luettu 8.9.2020).

Jahnukainen, Markku \& Korhonen, Anu 2003. Integration of students with severe and profound intellectual disabilities into the comprehensive school system: teachers perceptions of the education reform in Finland. International Journal of Disability, Development and Education 50 (2), 169-180.

Jahnukainen, Markku, Pösö, Tarja, Kivirauma, Joel \& Heinonen, Hanna 2012. Erityisopetuksen ja lastensuojelun kehitys ja nykytila. Teoksessa Jahnukainen, Markku (toim.), Lasten erityishuolto ja -opetus Suomessa. 13. painos. Lastensuojelun keskusliitto. Tampere: Vastapaino, 15-54. 
Jahnukainen, Markku, Vainikainen, Mari-Pauliina, Lintuvuori, Meri, Asikainen, Mikko, Keskinen, Hanna-Leena, Hotulainen, Risto 2018. Tehostettua ja erityistä tukea saaneiden oppilaiden sijoittuminen toisen asteen opintoihin. Teoksessa Mari-Pauliina Vainikainen ym. Oppimisen tuki varhaislapsuudesta toisen asteen siirtymään: tasa-arvon toteutuminen ja kehittämistarpeet. Valtioneuvoston selvitys- ja tutkimustoiminnan julkaisusarja 55/2018, 87-93.

[www-lähde]. < https://julkaisut.valtioneuvosto.fi/bitstream/handle/

10024/161062/55-2018-Oppimisen_tuki_loppuraportti_27.9..pdf?sequence= 4\&isAllowed $=\mathrm{y}>$ (Luettu 8.9.2020)

Johnson, Peter \& Kiilakoski, Tomi 2020. Oppivelvollisuuden laajentaminen 2021? Arviointia undistuksen kestävyydestä ja vaikuttavampia vaihtoehtoja. Elinkeinoelämän keskusliitto.

[www-lähde]. <https://ek.fi/wp-content/uploads/2020/11/

Oppivelvollisuusuudistus_raportti_Final_ok.pdf> (Luettu 1.11.2020).

Kirjavainen, Tanja, Pulkkinen, Jonna \& Jahnukainen, Markku 2014a. Erityisopetuksen järjestämisen muutokset kunnissa 2000-luvulla. Kunnallistieteellinen aikakauskirja 42 (3), 306-323.

Kirjavainen, Tanja, Pulkkinen, Jonna \& Jahnukainen, Markku 2014b. Perusopetuksen erityisopetus-järjestelyt eri ikäryhmissä vuosina 2001-2010. Kasvatus 45 (2), 152-166.

Kirjavainen, Tanja, Pulkkinen, Jonna \& Jahnukainen, Markku 2016. Special education students in transition to further education: A four-year register-based follow-up study in Finland. Learning and Individual Differences 45 (1), 33-42.

Kivirauma, Joel 1987. Poikkeavuus ja kansanopetus ennen oppivelvollisuuta. Tutkimus heikkolahjaisiin ja pahantapaisiin oppilaisiin kohdistettujen toimenpiteiden muotoutumiseen vaikuttaneista tekijöistä erityisesti Turun ja Tampereen kansakouluissa. Turun yliopisto. Kasvatustieteiden tiedekunta. Julkaisusarja A:120.

Kivirauma, Joel 1989. Erityisopetus ja suomalainen oppivelvollisuuskoulu vuosina 1921-1985. Turun yliopisto. Kasvatustieteiden tiedekunta. Julkaisusarja A:145.

Kivirauma, Joel 1995. Koulun varjossa. Entiset tarkkailuoppilaat kertovat koulukokemuksistaan. Jyväskylän yliopisto. Research reports. Department of Special Education.

Kivirauma, Joel 2002. Erityisopetuksen historialliset kehityslinjat Suomessa. Teoksessa Jahnukainen, Markku (toim.), Lasten erityishuolto ja-opetus Suomessa. 11. Täydennetty painos. Juva: Lastensuojelun keskusliitto, 23-33.
Koro, Jukka \& Moberg, Sakari 1981. Tarkkailuluokan oppilaiden sijoittuminen yhteiskuntaan. Kokeilu-ja tutkimustoimisto. Helsinki: Kouluhallitus.

Lampinen, Osmo., Laukkanen, Erkki., Ravantti, Heikki., Rinne, Risto, Poropudas, Olli \& Volanen, Matti Vesa (2003). Kohti asiantuntijayhteiskunnan koulutuspolitiikkaa. Helsinki: Kirja kerrallaan.

Lasten erityishuolto ja-opetus Suomessa 1955. Lastensuojelun keskusliiton julkaisu N:o 14. Helsinki: Lastensuojelun keskusliitto.

Lintuvuori, Meri, Hautamäki, Jarkko \& Jahnukainen, Markku 2017. Perusopetuksen tuen tarjonnan muutokset 1970-2016 - erityisopetuksesta oppimisen ja koulunkäynnin tukeen. Kasvatus \& Aika 11 (4), 4-21.

[www-lähde]. <https://journal.fi/kasvatusjaaika/article/view/68762/30502> (Luettu 5.6.2020).

Lintuvuori, Meri 2019. Perusopetuksen oppimisen ja koulunkäynnin tuen järjestelmän kehitys tilastojen ja normien kuvaamana. Helsingin yliopisto. Kasvatustieteellinen tiedekunta. Helsinki Studies in Education, 51.

Meriläinen, Raija 2011. Valkolakki, haalarit vaiko molemmat? Koulutuspoliittisten vaikuttajien näkemykset toisen asteen kehittämisestä. SuPerin julkaisuja 1/2011. Helsinki: Unigrafia.

Meriläinen, Raija \& Varjo, Janne 2006. Nuorisokouluvision historiallinen rakentuminen osana suomalaista koulutusjärjestelmää ja -politiikkaa. Koulu ja menneisyys, Vol 51, 220-246. [www-lähde]. < https://journal.fi/koulujamenneisyys/article/ view/98986/56674 > (Luettu 10.10.2020).

Merimaa, Erkki 2011. Erityistä tukea tarvitsevien oppilaiden opetuksen järjestämisen ja siihen liittyvän lainsäädännön kehitys. Teoksessa Aho, Jaakko (toim.), Koulutus yhteiskunnallisen muutoksen airueena: Suomen koulubistoriallisen seuran vuosikirja XLIX (2011). Helsinki: Suomen kouluhistoriallinen seura, 171-197. [www-lähde]. <https://www.kasvhistseura.fi/dokumentit/1111140701_h_merimaa.pdf> (Luettu 6.5.2020)

Moberg, Sakari 1979. Leimautuminen erityispedagogiikassa: nimikkeisiin apukoululainen ja tarkkailuluokkalainen liittyvät käsitykset ja niiden vaikutus hypoteettista oppilasta koskeviin havaintoihin. Jyväskylä studies in education, psychology and social research 39. 
Moberg, Sakari 2002. Integraation ja inklusiivisen kasvatuksen ideologia ja kehittyminen. Teoksessa Jahnukainen, Markku (toim.), Lasten erityishuolto ja-opetus Suomessa. 11. Täydennetty painos. Juva: Lastensuojelun keskusliitto, 34-48.

Moberg, Sakari \& Ikonen, Oiva 1980. Integraatio kehitysvammahuollossa: käsiteanalyysi ja teoreettinen tausta. Psyykkisesti kehitysvammaisten integraatio Suomessa. Osaraportti 1. Valtakunnallisen tutkimus- ja kokeiluyksikön julkaisuja. Helsinki: Kehitysvammaliitto.

Mäki, Niilo 1951. Helsingin kaupungin apukoulujen entisten oppilaiden (1903-39) myöhemmät elämänvaiheet. Liite Helsingin kaupunginhallituksen mietintöön. Mietintö 27:2. Helsinki: Mercatorin kirjapaino, 25-55.

Naukkarinen, Aimo 2002. Oppiva koulu oppilaan yksilöllisyyden kohtaajana. Teoksessa Jahnukainen, Markku (toim.), Lasten erityishuolto ja-opetus Suomessa. 11. täydennetty painos. Juva: Lastensuojelun keskusliitto, 345-355.

Nirje, Bengt 1969. The normalization principle and its human management implications. Teoksessa Kugel, Robert. B. \& Wolfensberger, Wolf (toim.) Changing Patterns in Residential Services for Mentally Retarded. Washington DC: President's Committee on Mental Retardation, 179-188.

Numminen, Jaakko 2020. Sivistys-Suomen synty 1. Opetusministeriön kansliapäällikkö muistelee: Koulutuspolitiikka, Helsinki: Edita.

Paju, Birgit 2021. An Expanded Conceptual and Pedagogical Model of Inclusive Collaborative Teaching Activities. University of Helsinki. Faculty of Educational Sciences. Helsinki: Unigrafia.

Pirttimaa, Raija, Räty, Lauri, Kokko, Tiina \& Kontu, Elina 2015. Vaikeimmin kehitysvammaisten lasten opetus ennen ja nyt. Teoksessa Jahnukainen, Markku, Kontu, Elina, Thuneberg, Helena \& Vainikainen, Mari-Pauliina (toim.), Erityisopetuksesta oppimisen ja koulunkäynnin tukeen. Kasvatusalan tutkimuksia 67. Turku: Suomen kasvatustieteellinen seura ry, 179-200.

Pulkkinen, Jonna 2019. Reforming Policy, Changing Practices? Special Education in Finland After Educational Reforms. Tutkimuksia 34, Koulutuksen tutkimuslaitos. Jyväskylä.: Jyväskylän yliopisto.

Pulkkinen Jonna \& Jahnukainen, Markku 2016. Finnish Reform of the Funding and Provision of Special Education: The Views of Principals and Municipal Education Administrators. Educational Review 68 (2), 171-188.
Pulkkinen, Jonna, Räikkönen, Eija, Jahnukainen, Markku \& Pirttimaa, Raija 2020. How do educational reforms change the share of students in special education? Trends in special education in Finland. European Educational Research Journal 19 (4), 364-384

Sahlstedt, Heli 2015. Pedagogisesti yhtenäinen peruskoulu. Tapaustutkimus opettajien, oppilaiden ja huoltajien näkemyksistä. Helsingin yliopisto. Opettajankoulutuslaitos. Tutkimuksia 364.

SVT 2020. Erityisopetus. Helsinki: Tilastokeskus.

[www-lähde]. <https://www.stat.fi/til/erop/index.html> (Luettu 8.3.2021).

Tuunainen, Kari 2002. Vammaishuollon historialliset kehityslinjat Suomessa.

Teoksessa Jahnukainen, Markku (toim.), Lasten erityishuolto ja-opetus Suomessa. 11. täydennetty painos. Juva: Lastensuojelun keskusliitto, 13-22.

UNESCO 1994. Final Report. World Conference in Special Needs Education. Access and Quality. Salamanca, Spain, 7-10 June. Paris: UNESCO.

Virtanen, Pirkko. 2002. Erityishuoltoa ja opetusta koskeva lainsäädäntö. Teoksessa Jahnukainen, Markku (toim.), Lasten erityishuolto ja-opetus Suomessa. 11. täydennetty painos. Juva: Lastensuojelun keskusliitto, 49-66.

Volanen, Matti Vesa 2000. Yksilöllistyvä peruskoulu, yksipuolistava nuorisoasteen koulutus. Teoksessa Raivola, Reijo (toim.), Vaikuttavuutta koulutukseen. Suomen Akatemian koulutuksen vaikuttavuusohjelman tutkimuksia. Helsinki: Edita, 71-97.

Wishart, Diane \& Jahnukainen, Markku 2010. Difficulties associated with the coding and categorization of students with emotional and behavioural disabilities in Alberta. Emotional and Behavioural Difficulties 15 (3), 181-187.

\section{Lait, asetukset ja säädökset}

Apukouluasetus 53/1952

Asetus kuuromykkäin ja sokeain oppilaitoksista (372/1934)

HE 86/1997 vp Hallituksen esitys Eduskunnalle koulutusta koskevaksi lainsäädännöksi. [www-lähde]. https://www.eduskunta.fi/FI/vaski/HallituksenEsitys/Documents/he_86+1997.pdf (Luettu 12.11.2020) 
Hallituksen esitys HE 173/2020 vp Hallituksen esitys eduskunnalle oppivelvollisuuslaiksi ja eräiksi siihen liittyviksi laeiksi

[www-lähde]. <https://www.eduskunta.fi/FI/vaski/HallituksenEsitys/Documents/ HE_173+2020.pdf> (Luettu 10.10.2020)

Invaliidihuoltolaki (947/1946)

\section{Kansakouluasetus (321/1958)}

Kansakoululaki (246/1957)

KM 1948:1. Komiteanmietintö uudistettavan koulujärjestelmän yleisten periaatteiden vahvistamiseksi. Helsinki: Valtioneuvoston kirjapaino.

KM 1959. Kouluohjelmakomitean mietintö. Komiteanmietintö 1959:11. Helsinki: Valtion painatuskeskus.

KM, 1965. Peruskoulukomitean osamietintö. N:o 1. 1965: A7. Helsinki: Valtion painatuskeskus.

KM 1970. Erityisopetuksen suunnittelutoimikunnan osamietintö I. 1970: A 16. Helsinki: Valtion painatuskeskus.

KM 1971. Erityisopetuksen suunnittelutoimikunnan osamietintö II. 1970: A 26. Helsinki: Valtion painatuskeskus.

Laki koulujärjestelmän perusteista 467/1967

LA 59/2014 vp. Laki oppivelvollisuudesta ja eräät muut siihen liittyvät lait. [www-lähde] <https://www.eduskunta.fi/FI/Vaski/sivut/trip.aspx?triptype=

ValtiopaivaAsiakirjat\&docid=la+59/2014> (Luettu 9.11.2020)

Laki perusopetuslain muuttamisesta 624/2010

Laki perusopetuslain muuttamisesta 1216/2020

Laki kunnan peruspalvelujen valtionosuudesta 1704/2009

Laki tutkintokoulutukseen valmentavasta koulutuksesta 1215/2020

Lukiolaki 714/2018
Luonnos hallituksen esitykseksi 7.5.2014. Hallituksen esitys eduskunnalle oppivelvollisuuslaiksi ja eräiden siihen liittyvien lakien muuttamiseksi. [www-lähde] <https://dev.hel.fi/paatokset/media/att/0b/0b9a537aba68bae3df581cbd18051078c 2d6278b.pdf > (Luettu 3.11.2020)

OPH 2011. Perusopetuksen opetussuunnitelman perusteiden muutokset ja täydennykset 2010. Määräykset ja ohjeet 2011:20. Helsinki: Opetushallitus.

OPH 2016. Perusopetuksen opetussuunnitelman perusteet 2014. 4. painos.

Helsinki: Opetushallitus.

OPH 2020. Pidennetty oppivelvollisuus. < https://www.oph.fi/fi/koulutus-ja-tutkinnot/pidennetty-oppivelvollisuus $>$ (Luettu 12.11.2020).

OPM 2007. Erityisopetuksen strategia. Opetusministeriön työryhmämuistioita ja selvityksiä 2007:47. Helsinki: Opetusministeriö.

Oppivelvollisuuslaki (101/1921)

Peruskoululaki 476/1983

Perusopetuslaki 628/1998

TPA 88/2009 vp Oppivelvollisuusiän nostaminen 18 ikävuoteen. [www-lähde] <https://www.eduskunta.fi/FI/Vaski/sivut/trip.aspx?triptype= ValtiopaivaAsiakirjat\&docid=tpa+88/2009> (Luettu 9.11.2020)

VN 2019. Pääministeri Sanna Marinin hallituksen ohjelma 10.12.2019. Osaava ja osallistava Suomi - sosiaalisesti, taloudellisesti ja ekologisesti kestävä yhteiskunta. [www-lähde] <http://julkaisut.valtioneuvosto.fi/handle/10024/161931>

(Luettu 1.9. 2020) 